\title{
Indicator-Based Assessment of Coping and Adaptive Strategies Against Flood Hazards in Tal and Diara Regions of Malda District, West Bengal (India)
}

Hiranmay Rishi ( $\nabla$ rishihiran@gmail.com )

North Eastern Hill University https://orcid.org/0000-0002-6286-3990

Subrata Purkayastha

North-Eastern Hill University

\section{Research}

Keywords: Flood disaster, Distance from the rivers, Tal and Diara, Resilience, Preparedness coping and adaptive index

Posted Date: August 11th, 2020

DOl: https://doi.org/10.21203/rs.3.rs-52304/v1

License: (c) (1) This work is licensed under a Creative Commons Attribution 4.0 International License.

Read Full License 


\section{Abstract}

Malda district of West Bengal is extremely vulnerable to floods. Yet this district reports high density of population suggesting that the people here must have adopted coping and adaptive strategies to meet the flood menace which is almost an annual affair. This paper addresses and compares the preparedness, coping and adaptive strategies of the local people at household level living in two distinct physiographic units viz. Tal and Diara of Malda. Further, an attempt is made whether the distance from the river plays any role in the coping and adaptive strategy of the villagers. This paper is empirical in nature, primary data has been generated through field investigation in two sets of villages of Tal and Diara, conducted in the month of September and October 2018. Field data has been quantified and measured to assess the level of resilience of the people to flood hazard/disaster. UNDP technique has been used for developing preparedness, coping and adaptive indexes. The score ranges between 0 and 1 , where higher the score higher is the level of resilience.

\section{Introduction}

Global warming and climate change is resulting in extreme weather conditions and increase in the frequency and intensity of weather-related phenomena like heavy rainfall which leads to hazards/disasters. Weather-related hazards like floods, landslides, cyclones are common phenomena affecting all countries but unlike the developed countries which have adequate risk reduction, preparedness and response infrastructure at both national and local level making their population more resilient to such hazards (World Bank, 2018). The population of developing countries are less resilient to such hazards as their resilience is less. India a developing economy reports high density of population, this increases the magnitude of any hazard/disaster as more people are exposed to such hazards consequently more life and livelihood and property loss are reported along with destruction of the limited infrastructure. Hazards/disasters related displacement of people is also common. In the last 20 years, it has been estimated that India suffered a whopping loss of US $\$ 79.5$ billion due to climate-related disasters (Wallemacq, 2018). This has attracted international attention, efforts are on to mitigate the impact of disasters with an increasing focus on human vulnerability (World Bank, 2018). Of all the disasters that regularly strike India, floods are probably the most recurrent, impacting large areas. Out of the total geographical area of 329 million hectares in India, more than 40 million hectares i.e. $12 \%$ of the land is prone to flood and riverbank erosion (NDMA Annual Report, 2018-19). The main cause of the devastating floods here are attributed to incessant heavy rainfall, cloudburst, snow melting and cyclones besides the antecedent condition of the catchment area, inadequate drainage, breach in flood control structures like embankments and dams as well as the levees (Agrawala et al., 2003; Jonkman, 2005; Ghatak et al., 2012; Doocy et al., 2013).

Malda district of West Bengal falls in North Bengal categorized as highly flood-prone area receiving very heavy rainfall (annual average) ranging from $1100 \mathrm{~mm}$ to $1485 \mathrm{~mm}$ annually which occurs mostly during the months of monsoon (District Statistical Handbook, 2014; District Disaster Management Plan, 2017). 
that the local population have learned to adapt to such situations suggesting resilience. Resilience to flood is a useful concept to investigate at the local level as the capacity of rural households to cope with and adapt to floods and to live with floods (Nguyen \& James, 2013). Resilience develops when there are preparedness, coping and adaptive strategies to face the ill impact of a hazard. Preparedness involves equipping people to face the adversities of the hazard/disaster so as to increase the survival and minimize economic and other losses associated with a disaster (Jha, 2010). Coping capacity refers to the immediate response of the community or institutions or both taking actions to reduce or eliminate the adverse impact of disaster which have occurred or are currently occurring in order to prevent further suffering and financial loss (Coppola, 2007). While adaptive strategies refer to the recovery phase which aims to restore the victim's lives to normal/previous conditions following the impact of a disaster (Haddow \& Bullock, 2004; Coppola, 2007). Thus coping and adaptive strategies involve managing resources both in normal times as well as during crisis or adverse conditions (UN/ISDR, 2004). Coping and adaptive approach to disaster management involves three stages viz. preparedness, immediate coping and long term adaptive strategies adopted by the people with or without institutional help to build resilience against a particular disaster. This paper addresses the preparedness, coping and adaptive strategies adopted at village and household levels by the rural population living in two physiographic units viz. Tal and Diara in Malda district of West Bengal.

\section{Study Area}

Malda located in the north part of West Bengal is extremely flood-prone. This district is predominantly rural, drained by major rivers viz. Ganga, Mahananda, Fulhar, Kalindri, Pagla, Tangan, and Punarbhaba laden with silt, flowing to Bangladesh in the south-east (District Disaster Management Plan, 2017; Ghosh \& Kar, 2018). Both physical and technological factors make Malda prone to flood hazards. The construction of Farakka barrage (having a length of $2.64 \mathrm{~km}$ ) to restrict the natural flow of Ganga and divert 87 cubic meters of water to resuscitate the port of Kolkata, has changed the geo-hydraulic regime of the area and Malda located upstream has become more prone to flood hazards (Banerjee, 1999; Parua, 1999, 2002; Sengupta, 2001; Iqbal, 2010). Studies (Parua, 1999, 2002; Rudra, 2000, 2018) suggest that historically river Ganga keeps shifting its course here and the construction of Farakka barrage here has aggravated this problem as the river has to adjust to the new hydraulic system resulting in bank erosion and floods. Hence both natural and technological factors have aggravated flood hazards here.

Figure 1 Study area

Malda district has three physiographic units (Fig. 1) viz. Barind is composed of lateritic or the older alluvial humps are remnants of older flood plain, occupying comparatively higher ground therefore less prone to flood hazards (Laha, 2015). Tal is a marshy tract, mostly composed of older alluvium, bog lands found as pockets in the flood plain around shrinking inland drainages, prone to floods during rainy season (Sahana et al., 2015). The Tal gradually slopes towards the south-west and merges with the next physiographic unit i.e. Diara. Diara as the name suggests is bounded by rivers (on three sides) and is a 
The alluvium deposits here are enriched almost annually by the annual floods, making it extremely fertile, thereby ideal for agriculture and associated livelihoods (Mukherjee \& Pal, 2017). Both Tal and Diara are densely populated in spite of being flood-prone which often turns into a hazard (Bose, 1986). Numerous rivers crisscross both Tal and Diara that overflow during the monsoon season yet studies (District Human Development Report, 2007; District Disaster Management Plan, 2017) suggest that river Ganga in Diara and river Fulhar in Tal causes maximum flood hazard in these two units.

\section{Objective}

The main objectives of this paper are- to assess and compare the level of preparedness, coping and adaptive strategies adopted by the local population at household level to meet the adversities associated with flood menace living in the two physiographic units viz. Tal and Diara of Malda district. Further, an attempt has also been made to assess if the level of preparedness, coping and adaptive strategies of the people here differ as per the distance from river Ganga in Diara and Fulhar in Tal which are the main rivers causing devastating floods.

\section{Materials And Methods}

The present study is empirical in nature where primary data has been generated through field investigation conducted in the month of September and October 2018 in two sets of villages, one set of villages located close to the river Fulhar in Tal and river Ganga in Diara and the other set of villages located at a distance from the respective rivers viz. Fulhar in Tal and Ganga in Diara (Fig. 1). Primary data has been generated at two levels-

Qualitative data generated through focus group discussion with the help of village elders, has helped in the general understanding of the flood situations in these villages especially the loss of livelihoods, settlements, infrastructure, life and livestock in general with a focus on the last major flood event of August 2017 and the resilience of the local population at community level, their level of preparedness to cope and adapt to the adversaries suggesting their resilience to floods.

Quantitative data has been generated through household survey with the help of a semi-structured schedule in the selected sets of villages- first set- comprising of villages Maniknagar in Tal (located close to Fulhar river) and Gopalpur in Diara (located close to Ganga river). The second set of villages comprising of Ratua in Tal and Nurpur in Diara located comparatively at a distance from the respective rivers viz. Fulhar and Ganga (Fig. 1).

A stratified random sampling technique has been followed for conducting the household survey in the two sets of villages. Information on selected indicators suggesting the level of preparedness, immediate coping and long term adaptive strategies to combat flood menace has been taken from each household, quantified and measured by computing Preparedness Index (PI), Immediate Coping Index (ICI) and Adaptive Index (AI). A composite index i.e. Resilience Index (RI) derived from the $\mathrm{PI}, \mathrm{ICl}$ and $\mathrm{Al}$ has been 
computed to assess the level of resilience at the micro-level in the two sets of villages. The score indices have been developed by the UNDP (2000) technique. The scores range between 0 and 1 where higher the score higher is the preparedness, coping and adaptive strategies of the households. The formula to construct the indices:

$$
P I / I C I / A I=\frac{X_{i j}-A_{\min }}{A_{\max }-A_{\min }}
$$

1

Where, $P /$ denotes Preparedness Index; $I C /$ denotes Immediate Coping Index; $A /$ denotes Adaptive Index; $X_{i j}$ is the actual value of $i^{\text {th }}$ variable at $j^{\text {th }}$ category; $A_{\text {max }}$ is the maximum value of $i^{\text {th }}$ variable at $j^{\text {th }}$ category and $A_{\min }$ is the minimum value of $i^{\text {th }}$ variable at $j^{\text {th }}$ category.

\section{Sample Size}

A total number of 712 households have been surveyed in the two sets of villages. The surveyed villages are having a large number of households (Table 1). The following formula (Creative Research Systems, https://www.surveysystem.com/sscalc.htm) has been used to select the number of households to be surveyed in each village:

$$
S S=\frac{Z^{2} \times(p) \times(1-p)}{C^{2}}
$$

2

Where, SS denotes sample size; $Z$ refers to standard score corresponding to a given confidence level (e.g. 1.96 for $95 \%$ confidence level); $p$ is the percentage picking a choice, expressed as decimal (e.g. 0.5 used for sample size needed) and $C$ is the confidence interval, expressed as decimal (e.g., $0.04= \pm 4$ ).

\section{Correction for finite population}

$$
S S=\frac{S S}{1+\frac{S S-1}{P}}
$$

3

Where, $P$ is the Population 
Table 1

Sampling framework for this study

\begin{tabular}{|c|c|c|c|c|c|c|}
\hline Region & C.D.Block & Village & $\begin{array}{l}\text { Total } \\
\text { households }\end{array}$ & $\begin{array}{l}\text { Sample } \\
\text { households }\end{array}$ & $\begin{array}{l}\text { Confidence } \\
\text { level }\end{array}$ & $\begin{array}{l}\text { Confidence } \\
\text { interval** }\end{array}$ \\
\hline \multirow[t]{2}{*}{ Tal } & Ratua-I & Maniknagar & 1880 & 178 & $95 \%$ & 7 \\
\hline & & Ratua & 1224 & 170 & $95 \%$ & 7 \\
\hline \multirow[t]{2}{*}{ Diara } & Manikchak & Gopalpur & 2010 & 180 & $95 \%$ & 7 \\
\hline & & Nurpur & 2933 & 184 & $95 \%$ & 7 \\
\hline \multicolumn{7}{|c|}{${ }^{* *} \pm 7$ is the margin of error } \\
\hline
\end{tabular}

\section{Choice of Indicators}

Information on 21 indicators suggesting the level of preparedness, immediate coping and adaptive strategies adopted by the households living in these two sets of villages have been used to develop the aggregate score of $\mathrm{PI}, \mathrm{ICl}$ and $\mathrm{Al}$. Out of the total indicators, 6 indicators are associated with preparedness to floods 7 indicators are related to immediate coping strategies and 8 indicators are related to adaptive strategies adopted by the households in the two sets of villages in Tal and Diara (Table 2). 
Table 2

Information on selected indicators that were used in this study

\begin{tabular}{|c|c|c|}
\hline Components & Indicators & Units/Labels \\
\hline \multirow[t]{6}{*}{ Preparedness } & $\mathrm{HH}$ reporting saving food grains/foodstuffs & \multirow[t]{6}{*}{ Percentage } \\
\hline & $\mathrm{HH}$ reporting houses constructed on elevated stilts & \\
\hline & $\mathrm{HH}$ living in concrete structure & \\
\hline & $\mathrm{HH}$ reporting saving fuels & \\
\hline & $\mathrm{HH}$ reporting saving crops or seeds & \\
\hline & $\mathrm{HH}$ reporting having some type of insurance & \\
\hline \multirow{7}{*}{$\begin{array}{l}\text { Immediate Coping } \\
\text { Strategies }\end{array}$} & $\mathrm{HH}$ reporting selling their assets & \multirow[t]{7}{*}{ Percentage } \\
\hline & $\begin{array}{l}\mathrm{HH} \text { reporting placing their valuables on high raised shelves in } \\
\text { their respective houses }\end{array}$ & \\
\hline & $\mathrm{HH}$ reporting borrowing money to meet crises situation & \\
\hline & $\begin{array}{l}\text { HH reporting access to shelter in flood shelters/roads/other } \\
\text { higher places during flood events }\end{array}$ & \\
\hline & $\mathrm{HH}$ reporting access to relief materials & \\
\hline & $\begin{array}{l}\text { HH reporting access to institutional help (Govt/NGO) to meet } \\
\text { immediate needs }\end{array}$ & \\
\hline & $\begin{array}{l}\text { HH reporting access to Govt assistance during the evacuation } \\
\text { process }\end{array}$ & \\
\hline \multirow[t]{8}{*}{ Adaptive Strategies } & $\mathrm{HH}$ reporting diversification of livelihood practices & \multirow[t]{8}{*}{ Percentage } \\
\hline & Agricultural $\mathrm{HH}$ reporting cultivating multi crops in a year & \\
\hline & $\begin{array}{l}\text { Agricultural HH practices mixed farming (food and cash crops } \\
\text { both) }\end{array}$ & \\
\hline & Agricultural HH practices short duration crops & \\
\hline & Agricultural $\mathrm{HH}$ reporting using flood-resistant crops & \\
\hline & Agricultural HH reporting recovering flood-affected land & \\
\hline & $\begin{array}{l}\text { Farming } \mathrm{HH} \text { reporting shifting to off-farm and non-farm } \\
\text { activities }\end{array}$ & \\
\hline & $\begin{array}{l}\text { HH reporting migration of a member/members in search of } \\
\text { better livelihood opportunities }\end{array}$ & \\
\hline
\end{tabular}

\section{Results And Discussion}




\section{Disaster preparedness}

Disaster preparedness involves the activities undertaken to prepare a community to react when a disaster strikes (Altay \& Green, 2006). Adequate preparedness can significantly improve disaster response activities (UN/ISDR, 2004). Field investigation suggests that within Tal and Diara the surveyed villages located close to the river viz. Maniknagar and Gopalpur report significantly higher level of preparedness strategies in comparison to the interior set of villages located at a distance from the rivers Fulhar and Ganga viz. Ratua and Nurpur respectively (Fig. 2).

Note: Maniknagar (Located close to the river Fulhar) and Ratua (Located away from the river Fulhar) are the selected villages of Tal and Gopalpur (Located close to the river Ganga) and Nurpur (Located away from the river Ganga) are the selected villages of Diara.

Following indicators were selected to assess the preparedness of the households living in the selected sets of villages in Tal and Diara:

\section{a. Reserving foodstuffs}

This is the most common strategy households adapt to survive a crisis situation. Field investigation suggests that not only the poor households but also the relatively better-off households save food grains and keep reserves of foodstuffs like chire (flattened rice), gur (jaggery), chatu, muri (puff rice), atta (flour) etc. to meet their immediate hunger during the flood period. $88.6 \%$ of the respondents from Gopalpur in Diara and $74.5 \%$ of the respondents from Maniknagar in Tal stated that they are always keeping reserves of food items in their respective homes to meet crisis situations especially during periods of incessant rains. It is interesting to note that the respondents from the interior villages are less prepared for such crisis situations as only $12 \%$ and $6 \%$ of the respondents from Ratua and Nurpur respectively reports the same (Fig. 2). Mention must be made here that studies suggest that the livelihood failures and hunger associated with flood disaster can be temporarily avoided if storage of food is combined with wellconstructed infrastructure, low levels of perishability of the food stored, and high level of coordination across households and social groups (Agrawal \& Perrin, 2008).

\section{b. Houses constructed on elevated stilts}

Settlements in flood-prone areas are sometimes constructed on elevated stilts so that the floodwater can easily flow without causing much havoc. 'Raising of plinth' mechanism for protection of houses are a common practice in Bangladesh and South East Asian countries (Shafie \& Rahman, 2009). Construction of houses and toilets on an elevated plinth emerges as one of the most effective strategies adopted by the villagers to prevent floodwater from entering their houses located by the riverside (Aßheuer et al., 2013). Field investigation suggests that about $68 \%$ of the houses in Gopalpur and $63 \%$ of the houses in Maniknagar are built on stilts which lie at an average height of 5 feet from the ground allowing the free flow of floodwater, both these villages are located in low lying areas close to the river embankments (Fig. 1). The embankment is often breached during periods of incessant rain increasing the current and 
eventuality as their houses are built on stilts. The interior villages of Ratua and Nurpur report a lower level of preparedness as only $24 \%$ and $22 \%$ of the houses are constructed on stilts (Fig. 2). Both these villages are located in comparatively higher ground and are less affected by floods of low magnitude.

\section{c. Building materials}

Building material is one of the vital components of a household's adaptive capacity (Vincent, 2007; Sharma \& Patwardhan, 2008). Strong concrete structures usually resist floodwater effectively and prevent property loss during flood hazards. Field investigation suggests that despite the recurrence of floods, the riverside villages of both of the physiographic units viz. Maniknagar and Gopalpur, have almost $50 \%$ of its population living in Kutcha houses extremely susceptible to floods. In contrast, the interior villages of Ratua (54.66\%) and Nurpur (52.05\%) have more than half of the households living in concrete houses which are more resistant to floods (Fig. 2). This can be attributed to the fact that the riverside villages of Maniknagar and Gopalpur have a higher incidence of poverty.

\section{d. Storing of fuel}

Storing of fuel to meet the crisis associated with disaster is also an important preparedness strategy adopted by the disaster-prone population at the household level especially in areas where external and institutional help is rare or takes time to reach when a disaster strikes. Most rural households of India store fuel materials like ghute (mold of cow dung), kerosene, jute sticks etc. Among others, using cow dung as fuel is the most common and feasible technique to use and preserve fuel in alluvial plains of India and Bangladesh (Shafie \& Rahman, 2009). Field data suggest that the villages of Gopalpur (87\%) and Maniknagar (73\%) reports a higher share of respondents who store fuel materials like ghute, jute sticks and kerosene oil to meet their fuel demand in comparison to the interior villages of Ratua and Nurpur (Fig. 2).

\section{e. Saving crops or seeds}

Saving crops or seeds for future agricultural use after the floods recede is one of the key preparedness strategies used by the farmers of the selected villages, particularly the villages located close to the embankment of the rivers Fulhar and Ganga viz. Maniknagar in Tal and Gopalpur in Diara. Field data suggest that $61 \%$ of the respondents in Maniknagar save their crops and seeds against $38 \%$ of the respondents from Gopalpur who report the same (Fig. 2). This may be attributed to the fact that Maniknagar is predominantly an agricultural village where most of the households are into farming which is their major livelihood practice. This is not the case in Gopalpur which comprises more re-settled families as in this village rich agricultural land is being wiped out rapidly due to bank erosion. The interior villages of Ratua in Tal and Nurpur in Diara are less impacted by the annual floods, it is only when the floods are of high magnitude like the flood event of August 2017 that these villages get impacted, consequently, the share of respondents from these two villages reporting saving seeds for future use are as low as $10 \%$ and $4 \%$ respectively (Fig. 2 ).

\section{f. Access to insurance}


Vincent (2007) considers investment in insurance to protect assets from climate risk to be a manifestation of preparedness for any disaster. Unfortunately, field data suggest that in both the villages viz. Maniknagar and Gopalpur, less than $10 \%$ of its respondents have an insurance which is mainly life insurance of the head of the family (Fig. 2). Crop insurance and home insurance are absent in these two villages in spite of the fact that every year they are at the mercy of the rivers leading to mainly property loss. In contrast, almost a quarter of the respondents of Ratua $(24.1 \%)$ in Tal and Nurpur $(23.78 \%)$ in Diara report that they enjoy an insurance (Fig. 2). The low share of access to insurance in these villages can be attributed to the fact that people here are marginalized and do not have enough money to pay for the insurance policy.

\section{Coping Strategies}

Coping measures can be defined as immediate practices that people apply after the event occurs or is occurring in order to combat the destructive effects that accompany the event (Smit \& Wandel, 2006; Nelson et al., 2007). A community that develops healthy coping strategies tends to be more resilient towards any disaster. Field investigation suggests that the residents of Tal and Diara have developed significant immediate coping strategies in order to minimize the impact of flood disasters. Field data suggest that within Tal and Diara the surveyed villages located close to the river viz. Maniknagar and Gopalpur report significantly higher immediate coping strategies in comparison to the selected villages located at a distance from the rivers Fulhar and Ganga viz. the villages of Ratua and Nurpur respectively (Fig. 3).

Note: Maniknagar (Located close to the river Fulhar) and Ratua (Located away from the river Fulhar) are the selected villages of Tal and Gopalpur (Located close to the river Ganga) and Nurpur (Located away from the river Ganga) are the selected villages of Diara.

In order to assess immediate coping strategies of the surveyed villages of Tal and Diara information on the following indicators has been assessed:

\section{a. Selling of assets}

In the absence of institutional support households often adjust to the immediate shock of flood disasters in several ways such as reducing household expenditure and selling assets (Dewan, 2015). The main purposes of selling assets are to buy food and other essential items for survival (Opondo, 2013). Assets such as livestock, furniture, TV, mobile phone, bicycle, agricultural tools and appliances are basically sold by the households to supplement their income during floods or just after the flood has receded. Some households may also sell their livestock which not only provides them with hard cash but also reduces the cost incurred to maintain the livestock as it is prone to diseases in the aftermath of floods, or maybe hit by fodder shortage during the crisis period. Field data suggest that selling or mortgaging the assets of the households has emerged as one of the most reactive immediate coping strategies in the absence of any institutional support in the first set of villages located close to the river embankments of Fulhar and Ganga respectively. Figure 3 indicates that selling assets are more prevalent in Gopalpur where $84 \%$ of 
respondents of Maniknagar whose share is about $68 \%$ of the total respondents. This may be attributed to the fact that Gopalpur being more affected by erosion and loss of land due to floods and associated bank erosion has a higher incidence of poverty in comparison to Maniknagar. The interior set of villages viz. Ratua in Tal and Nurpur in Diara reports an insignificant share of less than $10 \%$ of the respondents selling their personal assets or mortgaging their land and other properties to meet their immediate needs during the last flood incident of August 2017 (Fig. 3).

\section{b. Placing of valuables on high raised shelves}

In flood-prone areas, the rural folks often place their valuables like important documents, foodstuffs, cell phones, radio, television etc. on high raised shelves in their respective houses as it keeps these valuables safe from the floodwaters. It is interesting to note that in both the villages of Gopalpur of Diara and Maniknagar of Tal reports a very high share of respondents i.e. $97.56 \%$ and $87 \%$ respectively who state that they prefer placing their valuables in high raised shelves to keep the valuables safe, sometimes even food and clothes are stored at high raised shelves especially during the free flow of floodwaters resulting to ground level submergence of settlements and infrastructure. Field data suggest that the interior villages of Ratua more than half of the respondents report the same but in Nurpur slightly above a quarter of the respondents report that they keep their valuables on high raised shelves (Fig. 3).

\section{c. Borrowing cash/kind}

To meet the immediate needs the poor households often resort to borrowing of cash or kind, this is a common practice among the residents of flood-prone areas although borrowing is not a long term solution (Ninno et al., 2001). As livelihood opportunities are extremely limited during flood events the poor villagers who have a hand to mouth existence with almost no savings often resort to borrowing money to cope with the crisis situation. The rural poor of South and South East Asian countries are rich in social capital and there are common trust, norms and social networks at the community level which makes them survive in any critical situation (Aßheuer et al., 2013). Field data suggest that $92 \%$ of the respondents from Gopalpur of Diara and $81 \%$ of respondents from Maniknagar of Tal resort to borrowing money from their neighbours and also from the village money lenders who often charge high-interest rate (Fig. 3). In contrast in the interior villages of Ratua and Nurpur, an insignificant number of respondents report borrowing money during the last flood incident of 2017. As the poor villagers of mainly Gopalpur and Maniknagar mostly recourse to borrowing money mainly from the village money lenders to meet their immediate needs they end up paying higher interest rates and getting further entrapped into the vicious cycle of poverty.

\section{d. Access to shelter}

As floodwater creates havoc and flows into the residences of the population living in the flood-prone areas impacting their lives and livestock, the affected population are forced to move to safer places along with their valuables and livestock. Where there are community flood shelters and relief camps set up by the administration and various non-government organizations usually the flood-affected population 
forced to leave their homes along with their livestock in the last major flood event of 2017 while slightly above $60 \%$ of the respondents from Maniknagar reported that they too were forced to leave their homes in the last major flood event of 2017. Ratua and Nurpur were also affected by the major flood event of 2017 and more than a quarter of the households each from both the villages had to move out who mainly took refuge in the school buildings located in their respective villages (Fig. 3).

\section{e. Access to relief materials}

Disaster strikes hardest the poorer section of society as they have limited capacity to respond and recoup themselves from such tragedies. Unlike the rich, the socio-economically marginalized section of population are more vulnerable to the impact of floods as they have limited resources and their access to resources also gets constrained in the absence of recouping capacity (Moench \& Dixit, 2004). Field investigation suggests that food scarcity is a certain aftermath in the flood-affected villages of Tal and Diara. Studies suggest that during any major flood event, most household responses are geared toward evacuation and relief (Banerjee et al., 2017). Unfortunately in both the sets of villages in Tal and Diara access to relief materials from external agencies during the major flood event of August 2017 were very nominal. The villagers are supposed to get relief materials like dry foods, tarpaulin, clothes, medicines etc. from government or non-government sources. But unfortunately only $21 \%$ of the respondents from Maniknagar and $8.58 \%$ of the respondents from Gopalpur reported some form of flood relief from Government agencies during the last flood event of 2017 in spite of the fact that both these villages were severely affected by the flood hazard/disaster (Fig. 3). In the absence of much institutional support, the community has developed its own coping strategies to meet the flood threat at the household level, being rich in social capital, the villagers here survive by sharing their food and other resources.

\section{Adaptive strategies}

Adaptive strategies refer to the long term recovery measures developed by the victims or provided to the victims by external agencies or both in order to overcome the adverse effect of the hazard/disaster and restore normal conditions following the impact of any disaster (Tompkins, 2005; Smit \& Wandel, 2006; Janssen, 2006; Nelson et al., 2007). Thus "adaptation" refers predominantly to long term strategies while "coping" to short or mid-term adjustments in order to minimize the adverse aftermaths of a disaster (Braun \& Aßheuer, 2011). Field study suggests that in both the sets of villages in Tal and Diara the villagers have adopted various strategies to fight the flood menace over the years. It is interesting to note that Maniknagar and Gopalpur report relatively higher adaptation strategies in comparison to the interior villages of Ratua and Nurpur. This suggests that the villages located close to rivers Fulhar and Ganga respectively being more prone to floods have adaptive strategies that differ from the interior villages of Ratua and Nurpur (Fig. 4).

Note: Maniknagar (Located close to the river Fulhar) and Ratua (Located away from the river Fulhar) are the selected villages of Tal and Gopalpur (Located close to the river Ganga) and Nurpur (Located away from the river Ganga) are the selected villages of Diara. 


\section{a. Diversification of livelihood practices}

Loss of major livelihood practices are one of the inevitable impacts of flood hazards as floods not only destroy crops but also leads to loss of land, the ultimate wealth of an agriculturalist household. Hence, livelihood adjustment and diversification of livelihood is a common practice for the poor households. In disaster-stricken areas, many households began to broaden their livelihood portfolios by combining several activities and engaging in new activities in order to promote sustainable outcomes (Collins, 2014). Figure 4 reveals that a higher percentage of respondents have not only changed their major livelihood practice but have also diversified their livelihood practice in order to sustain their families. In Gopalpur, $83 \%$ of the respondents report that they have expanded their income sources by diversifying their livelihood practices. A substantial section of households in this village stated that they have lost their agricultural land due to riverbank erosion and are presently agricultural labour force working in neighbouring villages, doing odd jobs to sustain their families. In Maniknagar $36 \%$ of the respondents stated that they have lost their major livelihood practice and have diversified their livelihood practices in order to sustain themselves and their families. Gopalpur is prone to bank erosion and frequent flood hazard, here farming households report agricultural land losses. Hence, the villagers here have diversified their livelihood like working in brick kilns, MGNREGA (Mahatma Gandhi National Rural Employment Guarantee Act) scheme has helped them. Construction site workers in the adjoining areas as well as other districts/states is also emerging as an important livelihood strategy. Conversely, the interior villages of Ratua and Nurpur report less number of households reporting change in their major livelihood practices and diversification of livelihood practices (Fig. 4).

\section{b. Intensity of cropping}

Multi cropping practice leading to greater intensity of cropping is emerging as an important adaptive strategy in agriculture to meet the flood menace in flood-prone areas (Banerjee, 2010; Das, 2015). This helps the farming households to emerge more resilient to flood hazard/disaster as they not only tend to increase their agricultural production but also earn more by introducing cash crops and minimize the loss from failure of the crops due to floods. Field investigation suggests that in the Kharif season more land is allocated to long stem rain fed Aman rice and jute which grow with floodwaters. Among the Rabicrops mention must be made of vegetable farming, mustard and pulses whose productivity is high taking the advantage of the soil moisture and renewal of rich alluvium annually by the floods. In Maniknagar $71 \%$ of farming households report multi-cropping with crops having different agricultural calendar thereby increasing the agricultural intensity and production. In Gopalpur where arable land is limited due to bank erosion $56 \%$ of the respondents report farming as their major livelihood practice they too are in multicropping (Fig. 4). In the interior villages of Ratua and Nurpur where the land gets inundated occasionally long stem rice is preferred which grows with the floodwater, more land is given to jute, pisciculture is also common especially in Ratua as it is located in a marshy topography. Surprisingly, in both the physiographic units, farmers do not have much knowledge about the latest flood-resistant crops, this indicates that there is low level of awareness, and less of institutional intervention to improve agriculture.

Loading [MathJax]/jax/output/CommonHTML/fonts/TeX/fontdata.js CrOPS)

Page $13 / 24$ 
Along with increase in cropping intensity and emergence of market and demand the farmers prefer to grow both cash and food crops. This has emerged as one of the ways to avoid flood risk especially for Kharif or monsoon crops (Banerjee et al., 2017). In the villages of Gopalpur and Maniknagar, even the marginal and small farmers are growing both food and cash crops. Figure 4 indicates that in Maniknagar $61.54 \%$ of respondents grow both food and cash crops while in Gopalpur $40.7 \%$ of the respondents are growing both food and cash crops. Interestingly in interior villages viz. Ratua of Tal and Nurpur of Diara the agriculturalists are mainly into paddy and jute cultivation with less diversity of crops in comparison to the villages located close to the rivers. Farm mechanization such as the use of tractors in both physiographic units are common. It must be noted that tractors are usually owned by the village Panchayat or by large farmers and are given rented to smaller farmers.

\section{d. Growing of short duration crops}

In the villages of Maniknagar and Gopalpur, most of the farmers prefer to grow short duration crops which are harvested before the onslaught of floods e.g. Aus rice sown in March April and harvested in July. This minimizes crop loss due to floods. Some of the crops like rice, sugarcane, maize are harvested before the onslaught of flood fury. The Rabi crops e.g. vegetables, wheat, boro paddy, mustard, pulses are more intensely cultivated taking advantage of the soil moisture and high fertility of the soil enriched by receding floodwaters. It has observed from Fig. 4 that most of the farming households of the selected villages located on low land in close proximity to river Fulhar and Ganga viz. Maniknagar $(76.52 \%)$ and Gopalpur $(77.82 \%)$ report that they grow short duration crops. While an insignificant amount of agricultural households grow short duration crops in the interior villages of Ratua and Nurpur.

\section{e. Recovery of flood-affected agricultural land}

After the floodwater recedes the farmers here recover their cropland which otherwise would have turned to wasteland by cleaning the weeds and leaving the land fallow for at least two-three months. Then they plough and manure the fields and sow kalai, musur, khesari (types of pulses), tomatoes etc. along with mustard to revive the fertility of the soil. These pulses and vegetables do not need much labour or fertilizers but help in reviving soil nutrients necessary for other crops. Thus the population here revive back their farmlands from being degrading into wasteland. Field data suggest that in Maniknagar $86 \%$ of the respondents and in Gopalpur $82 \%$ of the respondents have adopted this method to battle against the onslaught of flood hazard (Fig. 4). Mention must be made here that after every major flood event the soil is replenished increasing soil fertility resulting in bumper crop productivity, thus despite the onslaught of flood hazard the farm population prefer to live here and the villages report high density of population. In the interior villages of Ratua and Nurpur, an insignificant percentage of respondents are into recovering their cropland from turning into barren land as here the villagers are comparatively less affected by floods.

\section{f. Shift to off-farm and non-firming activities}

Floods and bank erosion has resulted in loss of crops and croplands in Malda. Moreover, subsistence 
agriculture to non-farm and off-farm activities (District Human Development Report, 2007). Field investigation suggests that off-farm and non-farm activities are emerging as one of the major adaptive strategy followed in the villagers of Diara particularly in Gopalpur where $82.33 \%$ of farming households have shifted to off-farm activities like working in mango orchards, sericulture, pisciculture and non-farm activities like wage labour in brickfields and construction sites, petty business and other odd jobs (Fig. 4). The marginal farmers not only sell their livestock but also cultivable land to meet their needs or set up small businesses as agriculture appears less lucrative. Strikingly in Gopalpur, there is higher percentage of respondents who report a shift from farm activities to non-farming activities as this village reports higher loss of cropland due to riverbank erosion. In Maniknagar above a quarter of the respondents (35\%) reports a shift from farm to off-farm and non-firming activities. In the interior village of Nurpur in Diara, only $32 \%$ of the respondents report shifting from farm activities to non-farm and off-farm activities. In Tal, the interior village of Ratua reports relatively higher share of shift to off-farm and non-farm activities as $36 \%$ of the respondents report livelihood diversification through horticulture mainly mango and litchi orchards, pisciculture in inland water bodies and sericulture (Fig. 4).

\section{g. Migration of household's member/members}

As floods and riverbank erosion damage and erode thousands of hectares of land supporting farming and settlements resulting in loss of livelihoods and growing poverty, thousands of people are displaced, especially in developing economies like India (Islam et al., 2007; lqbal, 2010; Mukherjee, 2011; Das, 2015). Thus out-migration emerges as an inevitable pro-active adaptive strategy to fight the flood menace. Malda is no exception to this and field investigation suggests that especially from the riverside villages of both Tal and Diara substantial outmigration occurs in search of better livelihood options. In Gopalpur, $85.35 \%$ of respondents reported that they have sent a member/members from their households outside their village/district/state against $65.2 \%$ of the respondents in Maniknagar who report the same. Most of the villagers prefer to go other states like Delhi, Mumbai, Bangalore, Kerala in search of better livelihood opportunities. These migrant labourers add to the family income through remittance at home. The interior villages of Tal and Diara viz. Ratua and Nurpur report comparatively lesser occurrence of out-migration of respondents in search of better livelihoods as a strategy to combat the flood menace, as these villages are relatively less affected by flood havoc thereby reporting comparatively less loss of livelihood, property and livestock (Fig. 4).

\section{Resilience to flood hazards}

\section{Preparedness Index (PI), Immediate Coping Index (ICI), Adaptive Index (Al) and Resilience Index (RI)}

In order to assess and compare the level of resilience to floods at the household/community level in the two sets of villages located in two physiographic units viz. Tal and Diara PI, ICl, Al and RI have been computed with the help of the mentioned indicators (Table 3). 
Table 3

$\mathrm{Pl}, \mathrm{ICl}, \mathrm{Al}$ and $\mathrm{RI}$ of two sets of villages in Tal and Diara

\begin{tabular}{|lllll|}
\hline $\begin{array}{l}\text { Village/ } \\
\text { Region }\end{array}$ & $\begin{array}{l}\text { Preparedness } \\
\text { Index (PI) }\end{array}$ & $\begin{array}{l}\text { Immediate Coping } \\
\text { Index (ICI) }\end{array}$ & $\begin{array}{l}\text { Adaptation Index } \\
(\mathrm{Al})\end{array}$ & $\begin{array}{l}\text { Resilience Index } \\
(\mathrm{RI})\end{array}$ \\
\hline Maniknagar & 0.52 & 0.47 & 0.46 & 0.48 \\
\hline Ratua & 0.22 & 0.16 & 0.20 & 0.19 \\
\hline Tal & 0.37 & 0.32 & 0.33 & 0.34 \\
Gopalpur & 0.51 & 0.53 & 0.60 & 0.55 \\
\hline Nurpur & 0.19 & 0.14 & 0.15 & 0.16 \\
\hline Diara & 0.35 & 0.34 & 0.38 & 0.36 \\
\hline Source: Computed by authors & & & \\
\hline
\end{tabular}

It is interesting to note that in the final assessment, the coping and adaptive strategies developed by the villagers at household level are almost similar for both the physiographic units viz. Tal (0.36) and Diara (0.37) with slightly higher resilience towards floods for the Diara population who are more vulnerable to floods (Table 3; Fig. 5). It is the distance factor from the major rivers viz. Fulhar in Tal and Ganga in Diara which tends to play a role in the level of resilience to flood hazard/disaster (Fig. 5). The villages located close to the embankments of both the rivers report higher degree of resilience to floods ( 0.56 for Gopalpur and 0.51 for Maniknagar) in comparison to the interior villages of Ratua (0.20) located at about $4 \mathrm{~km}$ distance from Fulhar river and Nurpur (0.18) located at about $14 \mathrm{~km}$ distance from river Ganga the major flood producing river of Diara. This can be attributed to the fact that the villages located close to the embankments of the rivers are more vulnerable than the interior villages, hence their resilience in terms of preparedness, immediate coping and adaptive strategies are also higher in comparison to the village located at a distance from the major rivers (Fig. 5). In both the physiographic units the population have adapted to the flood menace which is almost an annual affair and developed an optimal farming system making Malda populous.

\section{Conclusion}

To conclude the floods here, despite the devastation that leads to life, livelihood and loss of property, it also brings opportunities for new livelihoods as the people here are busy restoring the breached embankments along with the floods, with the receding of flood waters creating opportunities to work and rebuild the flood damaged infrastructure. Regular floods also bring improved soil productivity as soil is enriched and naturally revitalized. Small landowners predominate in the surveyed villages along with landless poor people who crowd here despite the flood threat because they have developed coping and adaptive strategies for the moisture and susceptibility of their respective villages to flood hazards. Through this process, the villagers more susceptible to floods have developed a cropping pattern with an 
stay here amid the flood fury as with every flood event the soil gets enriched leading to a higher productivity. Hence this area reports high density of population in comparison to the state and the country.

\section{Declarations}

\section{Availability of data and materials}

Not applicable. Since our study is empirical.

\section{Competing interests}

The authors declare that they have no competing interests.

\section{Funding}

This work did not have any funding.

\section{Authors' contributions}

HR surveyed and collected necessary information, designed research framework, performed statistical analysis and drafted manuscript. SP reviewed and developed the manuscript. Both authors contributed to and approved the final manuscript.

\section{Acknowledgements}

We would like to thank the study respondents of the surveyed villages for volunteering information on which this study is based. Further the constructive comments from two reviewers are sincerely acknowledged.

\section{References}

1. Altay N, Green III, W. G (2006) OR/MS research in disaster operations management. Eur J Oper Res 175(1):475-493

2. Agrawal A, Perrin N (2008) Climate adaptation, local institutions, and rural livelihoods (IFRI Working Paper W081-6). Ann Arbor, Michigan: International Forestry Resources and Institutions Program and University of Michigan

3. Agrawala S, Raksakulthai V, van Aalst M, Larsen P, Smith J, Reynolds J (2003) Development and 
4. Aßheuer T, Thiele-Eich I, Braun B (2013) Coping with the impacts of severe flood events in Dhaka's slums -the role of social capital. Erdkunde, 21-35

5. Braun $B$, Aßheuer $T$ (2011) Floods in megacity environments: vulnerability and coping strategies of slum dwellers in Dhaka/Bangladesh. Natural hazards 58(2):771-787

6. Banerjee $L$ (2010) Effects of flood on agricultural productivity in Bangladesh. Oxf Dev Stud 38(3):339-356

7. Banerjee S, Kniveton D, Black R, Bisht S, Das PJ, Mahapatra B, Tuladhar S (2017) Do financial remittances build household level adaptive capacity? A case study of the flood affected households of Upper Assam in India

8. Bannerjee M (1999) A report on the impact of Farakka barrage on the human fabric. Report. World Commission on Dams-thematic review. South Asian Network on Dams, Rivers and People, New Delhi, India

9. Bose S (1986) Agrarian Bengal: economy, social structure and politics, 1919-1947

10. Bureau of Applied Economics \& Statistics, Government of West Bengal (2014) District Statistical Handbook, Malda, DSPI

11. Collins J (2014) A Rising Tide in Bangladesh: Livelihood adaptation to climate stress. Aust Geogr 45(3):289-307

12. Coppola DP (2006) Introduction to international disaster management. Elsevier, Amsterdam

13. Das M (2013) Socio economic and demographic consequences of river bank erosion in Majuli Island Assam

14. Doocy S, Daniels A, Murray S, Kirsch TD (2013) The human impact of floods: a historical review of events 1980-2009 and systematic literature review Apr 16. Review PLOS Currents: Disasters

15. Dewan TH (2015) Societal impacts and vulnerability to floods in Bangladesh and Nepal. Weather Climate Extremes 7:36-42

16. Disaster Management Department, Government of West Bengal (2017) District Disaster Management Plan of Malda. WBDMD

17. Development and Planning Department, Government of West Bengal (2007) District Human Development Report: Malda. HDRCC

18. Ghatak M, Kamal A, Mishra OP (2012) Background paper flood risk management in South Asia. In Proceedings of the SAARC workshop on flood risk management in South Asia

19. Ghosh A, Kar SK (2018) Application of analytical hierarchy process (AHP) for flood risk assessment: a case study in Malda district of West Bengal, India. Nat Hazards 94(1):349-368

20. Haddow GD, Bullock JA (2017) Introduction to emergency management. Butterworth-Heinemann, Amsterdam

21. Iqbal S (2010) Flood and erosion induced population displacements: a socio-economic case study in the Gangetic riverine tract at Malda district, West Bengal, India. Journal of Human Ecology 
22. Islam MZ, Islam MN, Akter ST (2007) Bank erosion of the river Meghna: Population displacement and socioeconomic impacts. Indian Journal of Power River Valley Development 57(10/11):241

23. Janssen MA (2006) Historical institutional analysis of social-ecological systems. Journal of Institutional Economics 2(2):127-131

24. Jonkman SN (2005) Global perspectives on loss of human life caused by floods. Natural hazards $34(2): 151-175$

25. Jha MK (ed) (2010) Natural and Anthropogenic Disasters: vulnerability, preparedness and mitigation. Springer Science \& Business Media, 1-16

26. Laha C (2015) Changing course of the river Ganga in Malda district West Bengal-Damage assessment and risk zone management

27. Moench M, Dixit A (2004) Adaptive capacity and livelihood resilience: adaptive strategies for responding to floods and droughts in South Asia. Institute for Social and Environmental Transition (ISET)

28. Mukherjee J (2011) No voice, no choice: riverine changes and human vulnerability in the 'chars' of Malda and Murshidabad. Occasional Paper, 28, Institute of Development Studies- Kolkata

29. Mehebub S, Raihan A, Nuhul H, Haroon S (2015) Assessing flood inundation extent and landscape vulnerability to flood using geospatial technology: a study of Malda district of West Bengal, India. Forum Geografic 14(2):156-163

30. Mukherjee K, Pal S (2018) Channel migration zone mapping of the River Ganga in the Diara surrounding region of Eastern India. Environment development sustainability 20(5):2181-2203

31. Nguyen KV, James H (2013) Measuring household resilience to floods: a case study in the Vietnamese Mekong River Delta. Ecology and Society, 18(3)

32. Nelson DR, Adger WN, Brown K (2007) Adaptation to environmental change: contributions of a resilience framework. Annual Review of Environmental Resources 32:395-419

33. Ninno CD, Dorosh PA, Smith LC, Roy DK (2001) The 1998 Floods in Bangladesh Disaster Impacts. Household Coping Strategies, and Response'(International Food Policy Research Institute, Washington DC, 2001)

34. National Disaster Management Authority (NDMA), Government of India. (2018-19). Annual Report. NDMA

35. Opondo DO (2013) Loss and damage from flooding in Budalangi District, Western Kenya. Loss and Damage in Vulnerable Countries Initiative, case study report. Bonn: United Nations University Institute for Environment and Human Security

36. Parua PK (1999) Erosion problems of the river Ganga in the districts of Malda and Murshidabad in West Bengal. Civil Engineering Today ASCE: Calcutta 13(2):3-20

37. Parua PK (2002) Farakka barrage-a multi-purpose project with dispute. Indian Journal of Power River Valley Development 52(11/12):248-260 
38. Rudra K (2018) Flood in the GBM Delta. In: Rivers of the Ganga-Brahmaputra-Meghna Delta. Springer, Cham, pp 125-136

39. Rudra K (2000) Living on the edge: the experience along the bank of the Ganga in Malda district, West Bengal. Indian Journal of Geography Environment 5:57-67

40. Shafie H, Rahman S (2009) Traditional coping strategies of rural people living in flood-prone areas in north-West Bangladesh. Rangpur Dinajpur Rural Service (RDRS), Dhaka

41. Sharma U, Patwardhan A (2008) An empirical approach to assessing generic adaptive capacity to tropical cyclone risk in coastal districts of India. Mitigation adaptation strategies for global change 13(8):819-831

42. Smit B, Wandel J (2006) Adaptation, adaptive capacity and vulnerability. Global environmental change 16(3):282-292

43. Sengupta N (2001) World commission on dams: Biased if misread. Economic Political Weekly 36(19):1647-1649

44. Tompkins EL (2005) Planning for climate change in small islands: insights from national hurricane preparedness in the Cayman Islands. Glob Environ Change 15(2):139-149

45. UN/ISDR, International Strategy for Disaster Reduction (2004) Living with Risk: A Global Review of Disaster Reduction Initiatives. UN Publications

46. United Nations Development Programme (UNDP) (2000) Human Development Report. Oxford University Press

47. Vincent K (2007) Uncertainty in adaptive capacity and the importance of scale. Glob Environ Change 17(1):12-24

48. World Bank (2018) Learning: To Realize Education's Promise. World Bank Group

49. Wallemacq P (2018) Economic losses, poverty \& disasters: 1998-2017. Centre for Research on the Epidemiology of Disasters, CRED

50. Creative Research Systems, https://www.surveysystem.com/sscalc.htm (Last access on 26.12.2019)

\section{Figures}




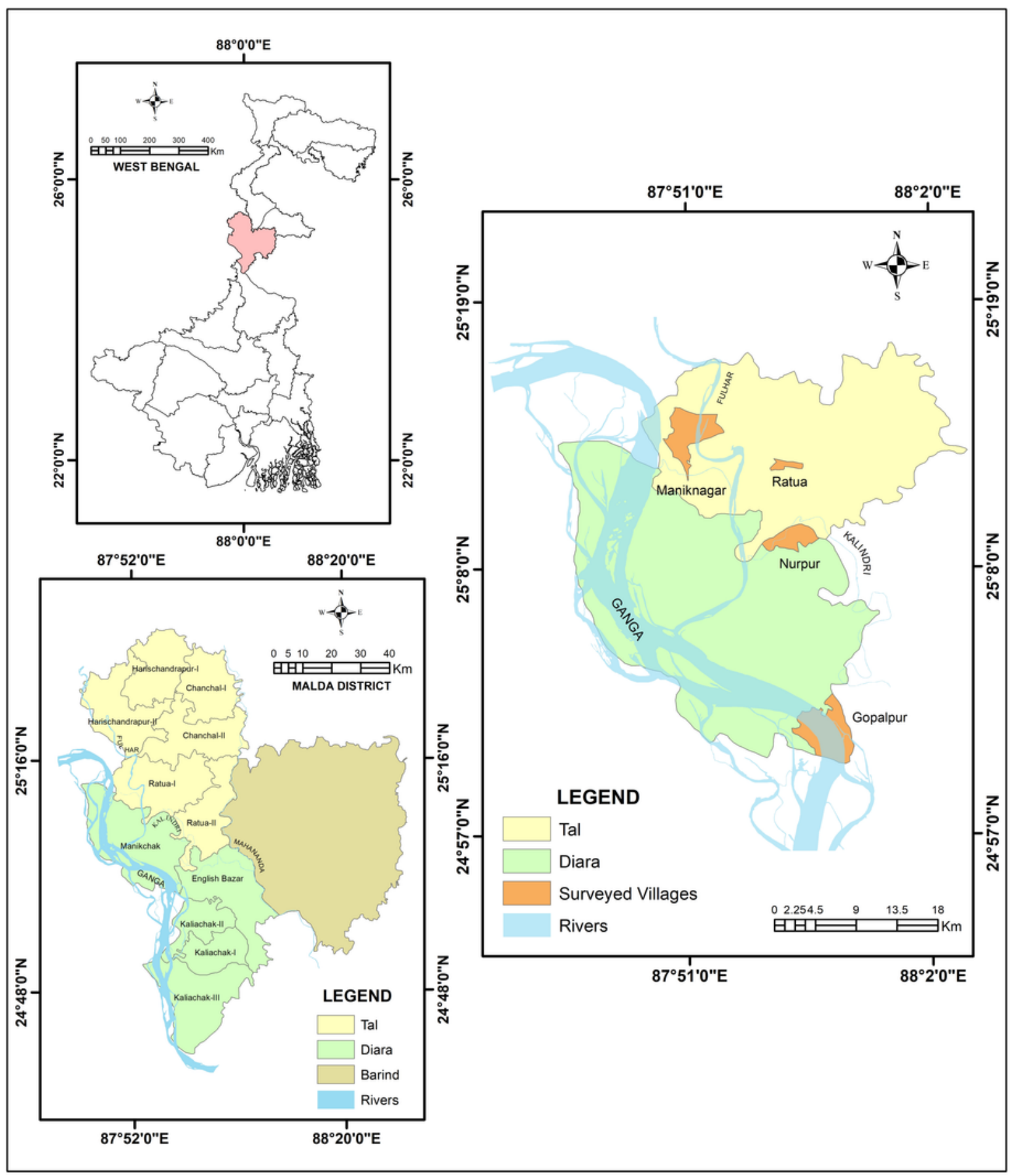

Figure 1

Study area 


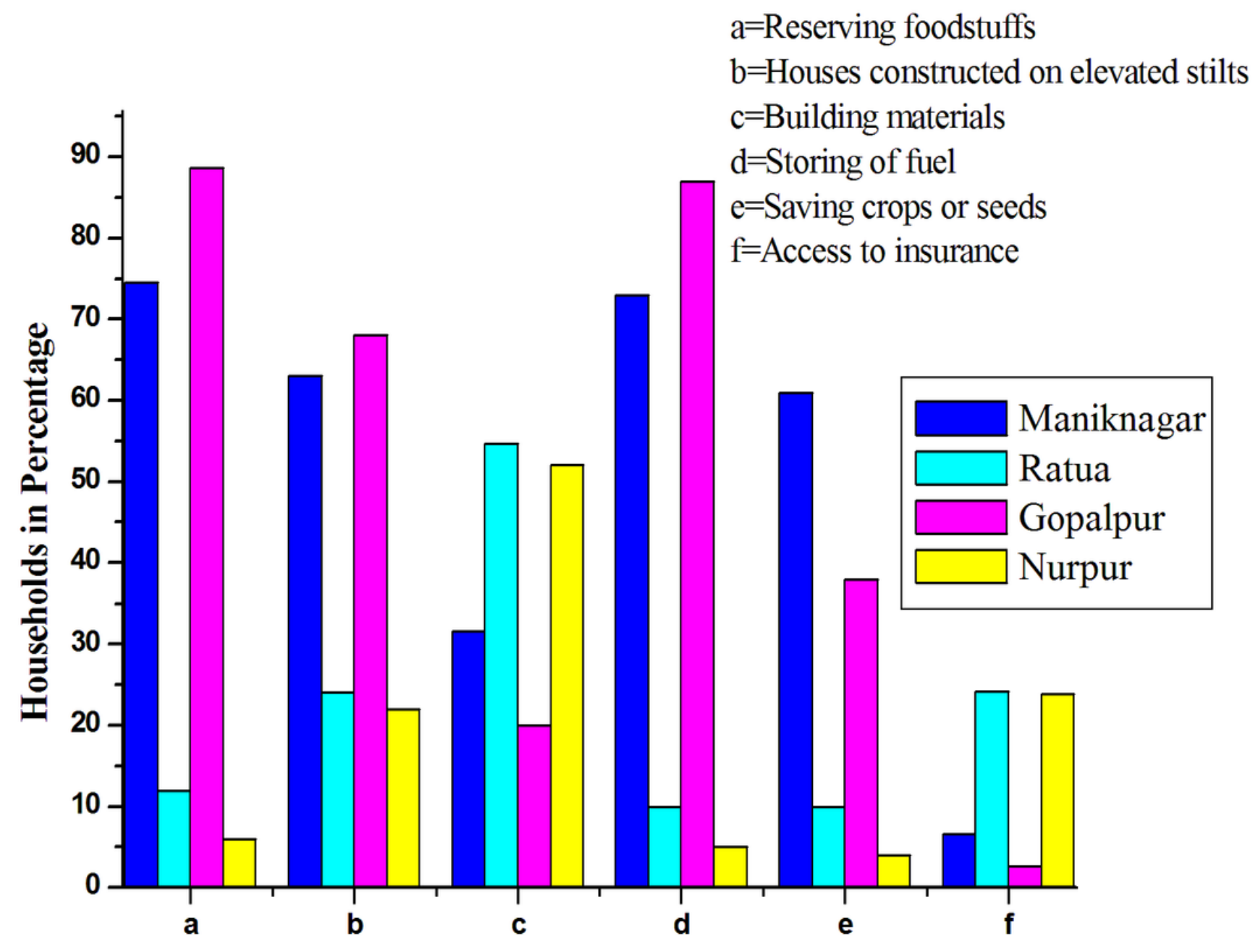

Figure 2

Preparedness level of the two sets of villages in Tal and Diara 


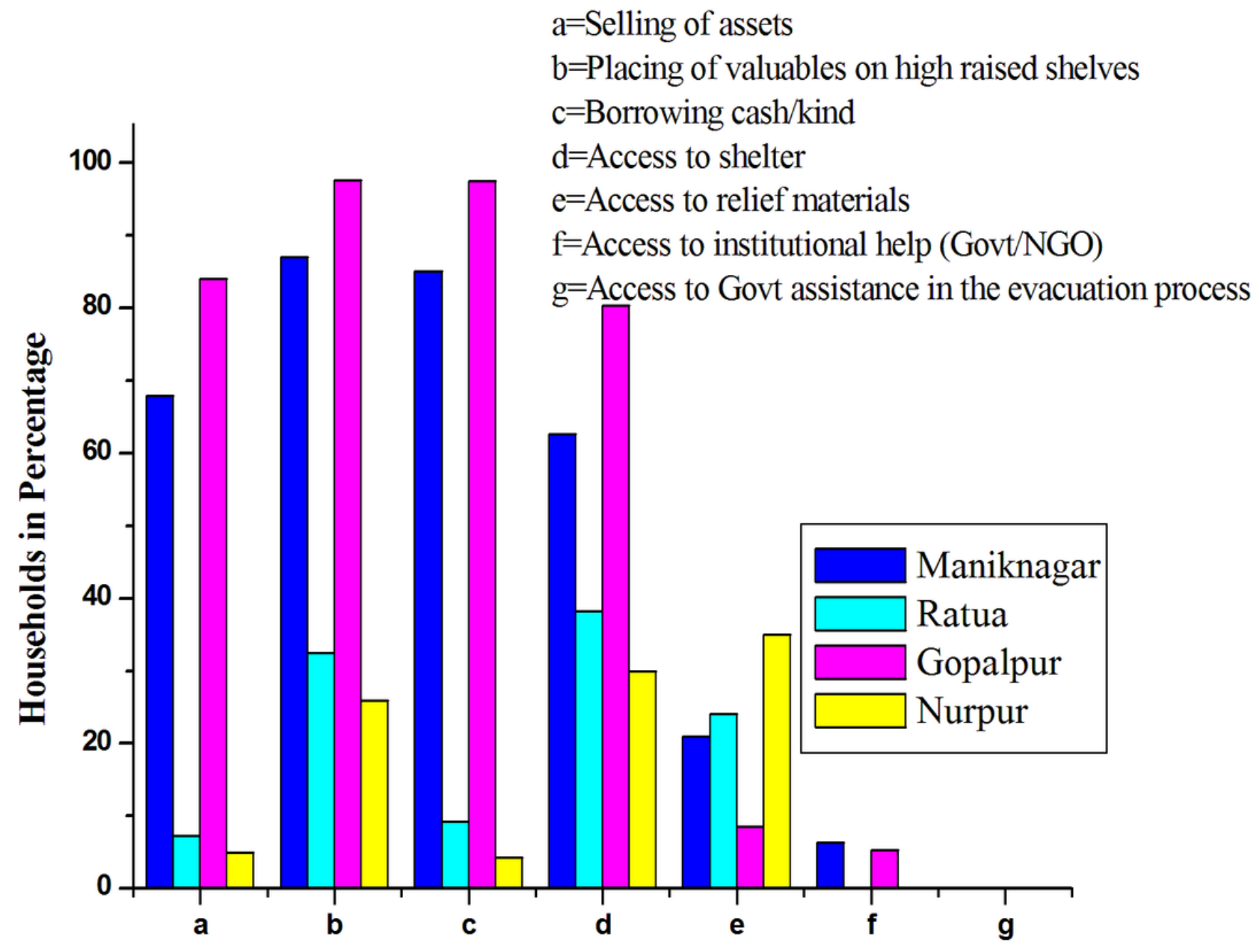

Figure 3

Coping strategies of the two sets of villages in Tal and Diara 
$\mathrm{a}=$ Diversification of livelihood practices

$\mathrm{b}=$ Intensity of cropping

$\mathrm{c}=$ Mixed farming (food and cash crops)

$\mathrm{g}=$ Shift to off-farm and non-farming activities

$\mathrm{d}=$ Growing of short duration crops

$\mathrm{e}=$ Growing flood resistant crops

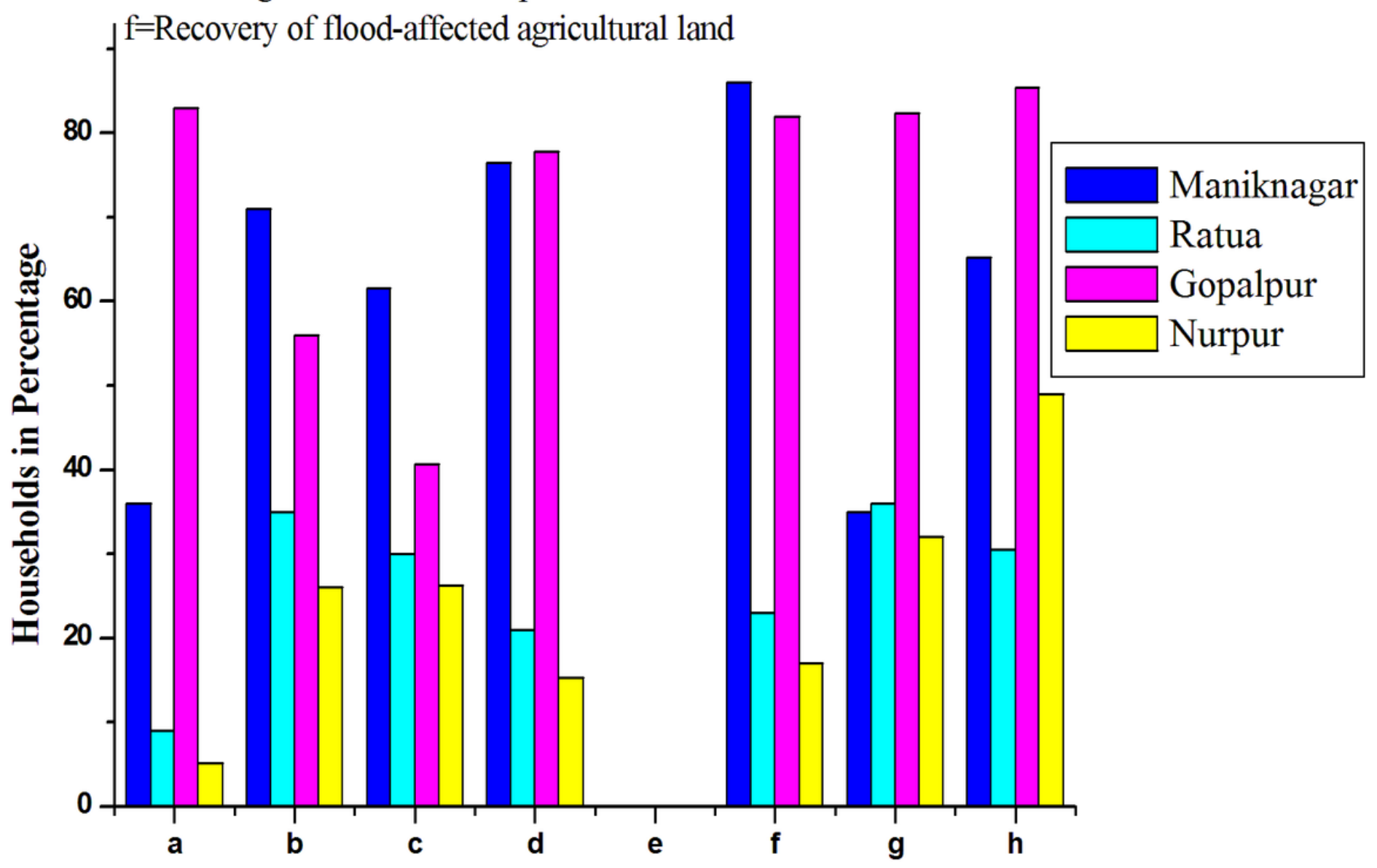

Figure 4

Adaptive strategies of the two sets of villages in Tal and Diara

A.

Figure 5

Level of resilience to flood hazards in the two sets of villages in Tal and Diara - a. PI, b. ICl, c. Al and d. RI 